\section{Incidental Ovarian Lesions}

우연히 접하는 난소 병변

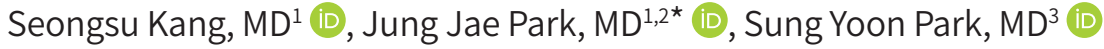 \\ ${ }^{1}$ Department of Radiology, Chungnam National University Hospital, Daejeon, Korea \\ 2Department of Radiology, Chungnam National University College of Medicine, Daejeon, Korea \\ ${ }^{3}$ Department of Radiology, Samsung Medical Center, Sungkyunkwan University School of Medicine, \\ Seoul, Korea
}

Incidental ovarian lesions are diagnostic challenges owing to their wide disease spectrum, ranging from normal findings to malignant ovarian tumors. There are several physiologic ovarian lesions that may not require any follow-up or treatment. While some lesions demonstrate their benign nature on imaging, some significant radiologic features may suggest malignant potential. Therefore, precise interpretation of imaging findings and proper recommendations for clinicians by radiologists are essential for managing incidental ovarian lesions to avoid unnecessary examinations or invasive treatments. The aim of this review is to describe the radiologic findings of commonly encountered incidental ovarian lesions on ultrasonography or computed tomography and to explain the management plan according to the stratified risk for malignancy in each ovarian lesion.

Index terms Ovarian Neoplasms; Ultrasonography; Computed Tomography, X-Ray; Differential Diagnosis

서론

초음파는 여성 생식기를 평가하는 데 있어 일차적인 영상 검사이다(1). 근래 부인과 초음 파 검사는 비단 영상의학과 의사뿐만 아니라 산부인과 의사에 의해서도 상당수 시행되고 있 고, 초음파에서 난소 병변이 흔히 발견된다. 또한 건강 검진을 포함하여 다른 목적으로 시행 하는 복부/골반 CT 건수가 지속적으로 증가하고 있는 만큼 CT에서 우연히 접하는 무증상 난소 병변의 빈도 역시 증가하고 있다. 하지만 CT는 일부 난소 병변을 평가하는데 다소 제한 적이다. CT 소견만으로 진단 가능한 경우가 있는 반면 초음파 또는 MRI를 추가로 시행해야 만 판단할 수 있는 경우도 많다. 게다가 모든 난소 병변이 치료 또는 일괄적인 추적 검사를 요하지는 않으며 심지어 판독에 기술할 필요 없는 정상적인 소견도 있다. 따라서 우연히 발 견된 난소 병변을 판독함에 있어 어려움이 있을 수 있다.

난소에 발생하는 고형성(solid) 종양은 병변이 연부 조직으로 구성되어 있고, 해당 부위에 도플러(Doppler) 초음파 검사상 혈류가 있거나 CT 또는 MRI에서 조영증강이 보이는 경우
Received July 31, 2019

Revised September 30, 2019

Accepted October 18, 2019

${ }^{*}$ Corresponding author Jung Jae Park, MD Department of Radiology, Chungnam National University Hospital, Chungnam National University College of Medicine, 282 Munhwa-ro, Jung-gu, Daejeon 35015, Korea.

Tel 82-42-280-8077

Fax 82-42-253-0061

E-mail jjskku@naver.com

This is an Open Access article distributed under the terms of the Creative Commons Attribution Non-Commercial License (https://creativecommons.org/ licenses/by-nc/4.0) which permits unrestricted non-commercial use, distribution, and reproduction in any medium, provided the original work is properly cited.

\section{ORCID iDs}

Seongsu Kang (i) https:// orcid.org/0000-0003-0278-7372 Jung Jae Park (D) https:// orcid.org/0000-0002-5212-9434 Sung Yoon Park (iD https:// orcid.org/0000-0003-0996-7595 
진단할 수 있다. 이러한 고형성 종양은 대부분 경계성(borderline) 또는 악성(malignant) 종양에 해당하기 때문에 수술로 제거함이 원칙이다(2-5). 일부 양성(benign) 종양 또는 전이성 악성 종양 이 의심되는 경우에도 영상 소견만으로 완벽히 감별하기 어렵고 경피적 조직 검사가 불가능한 경 우 진단적 수술을 시행한다. 즉 영상 판독 결과가 수술 방법과 범위를 결정하는 데 영향을 미칠 수 는 있지만 결국 진단 내지 치료 목적의 수술이라는 단일한 임상적 판단으로 귀결되는 점에서 영상 검사의 역할은 다소 축소된다(6). 하지만 난소의 낭종(cyst)은 추가 검사나 추적 관찰이 필요하지 않은 생리적 소견 및 치료가 필요 없는 양성 질환으로부터 반드시 치료가 필요한 악성 종양까지 매우 넓은 범위의 질환들을 포함한다. 이처럼 난소의 다양한 병변은 다음 네 가지 범주 중 하나로 구분하는 것이 영상 판독을 위해 유용하다. 첫째, 여성의 정상적인 생리 주기에 따라 생성과 소멸 을 반복하는 소견으로 판독에 반드시 언급할 필요는 없는 경우. 둘째, 판독에 기술해야 하는 양성 질환이지만 수술적 제거나 추적 관찰은 필요 없는 소견. 셋째, 양성 질환이지만 수술적 제거 대상 이며 제거하지 않을 경우 정기적인 추적 관찰이 필요한 병변. 넷째, 경계성 또는 악성 종양의 가능 성이 있어 추가 검사 내지 진단적 수술이 필요한 경우이며 앞서 언급한 고형성 난소 종양은 이 범 주에 해당한다. 따라서 난소 낭종을 판독함에 있어 상기 언급한 네 가지 범주 중 어디에 속하는지 판단하고 적절한 추가 검사나 추적 관찰을 권장하는 것이 중요하다.

우연히 접하는 무증상 난소 병변, 특히 난소 낭종에 대한 진단이 어렵고, 임상적 결정에 이견이 있는 점을 고려하여 이에 대한 권고안이 Society of Radiologists in Ultrasound에 의해 제시된 바 있다(7). 해당 권고안은 부인과, 영상의학과, 그리고 병리과의 전문가가 모여 토론하고 합의한 내 용에 근간하였다. 본 종설은 초음파 내지 CT 영상에서 우연히 접하는 난소 병변에 있어 감별해야 할 질환들의 영상 소견을 설명하고, 상기 권고안을 바탕으로 각각의 질환이 지니는 임상적 의미와 영상의학과 의사로서의 대처 방법을 설명하고자 한다.

\section{정상 난소}

정상 난소는 가임 연령대 및 생리 주기에 따라 다양한 모습을 보인다. 가임 여성의 경우 난소의 평균 부피는 약 $10 \mathrm{~mL}$ 이고 생리 주기에 따라 여러 개의 작은 난포(follicle)가 보이거나 1 2개의 우성난포(dominant follicle)가 보일 수 있다(Fig. 1) (8). 우성난포는 배란 전 가장 크지만 대개 $3 \mathrm{~cm}$ 이하이다 $(9,10)$. 배란 후 우성난포는 황체(corpus luteum)가 되며 황체 내부에 액체가 고여 커지 는 황체낭(corpus luteum cyst)은 특징적인 영상 소견으로 난포와 쉽게 구분된다(11). 배란이 일 어나지 않으면 난포낭(follicular cyst)이 되기도 하며 큰 경우 5 6 cm에 이른다. 폐경에 가까울수 록 난소의 부피 및 영상으로 확인 가능한 난포의 개수가 점점 감소한다. 폐경 후 난소는 매우 위축 된 상태를 보이며 정상적인 경우 $1 \mathrm{~cm}$ 이상의 낭종은 보이지 않는다(Fig. 2) (12, 13). 초음파로는 폐경 후 난소를 찾기 어렵고 CT에서도 주변 장기와 겹쳐있는 경우 확인이 어려운 경우가 많다.

난소에 비정상적인 낭종 내지 고형 종양이 발생할 경우 해당 병변은 정상 난소 구조를 심하게 누르고 대체하는 양상으로 커지므로 대개 정상적인 난소 구조가 소실된다. 따라서 자궁부속기 (adnexa)에 보이는 종괴의 기원 장기를 판단함에 있어 효율적인 방법은 정상 난소를 확인하는 것 
Fig. 1. Normal ovaries with follicles in a 25-year-old woman.

A. Axial contrast-enhanced CT image shows bilateral ovaries (arrows).

$B, C$. Right (B) and left (C) ovaries have multiple well-defined anechoic cysts suggesting the presence of follicles. A dominant follicle measuring $2 \mathrm{~cm}$ is located in the right ovary (asterisk).
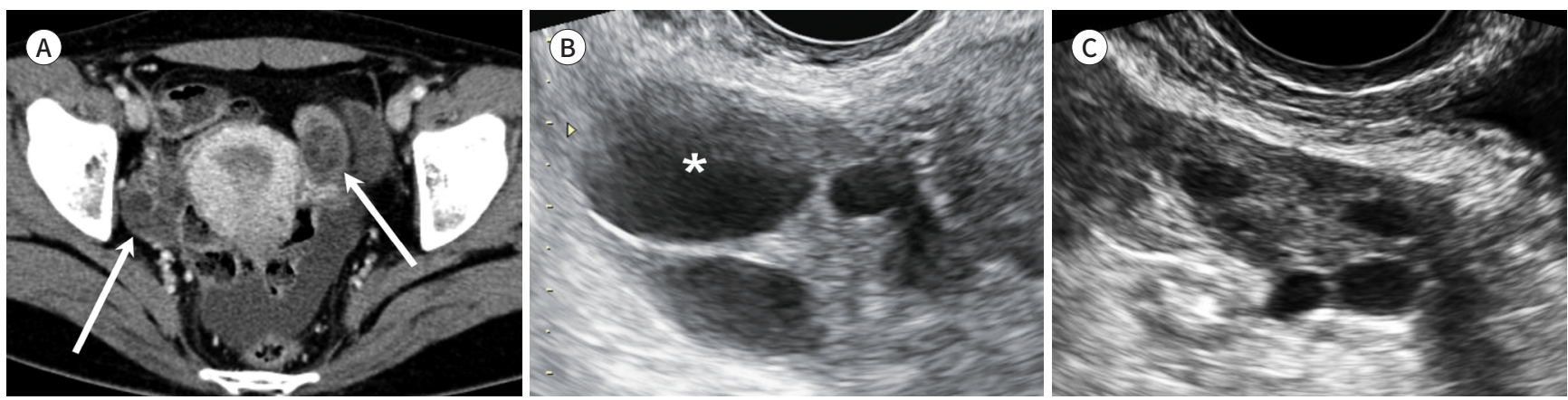

Fig. 2. Normal atrophic ovaries in a 58-year-old postmenopausal woman.

A, B. Axial (A) and coronal (B) contrast-enhanced CT images show atrophic band-like ovaries (arrows) without inner cystic structure.
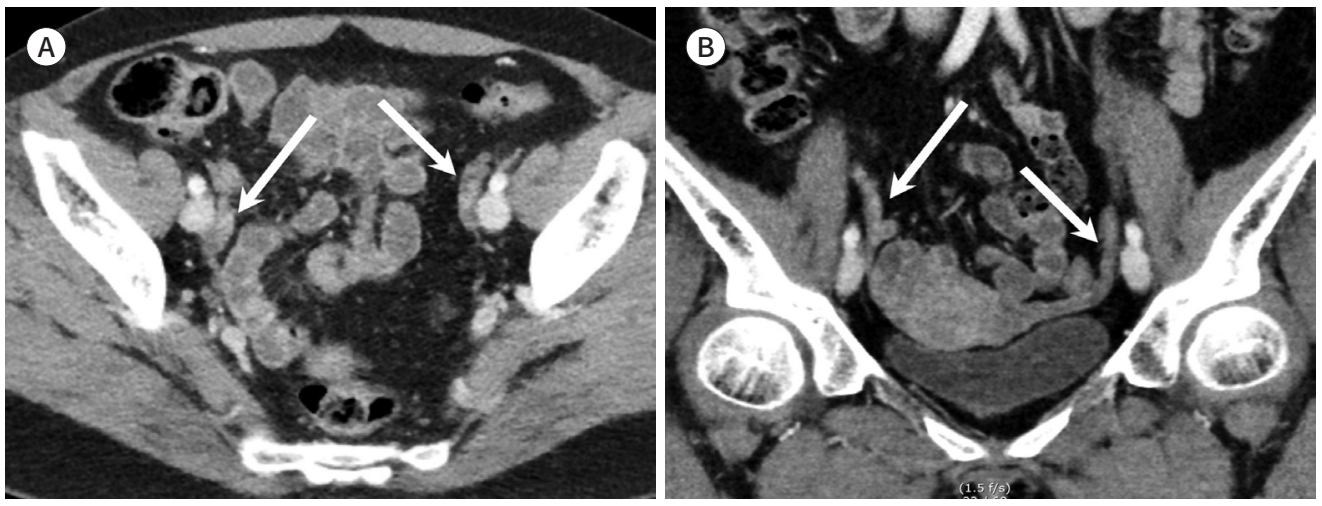

이다. 젊은 여성의 경우 난소의 부피가 상대적으로 크고 내부에 난포가 잘 보이기 때문에 초음파 나 CT에서 확인하기 쉽다. 하지만 나이가 들수록 상기 소견이 뚜렷하지 않고, 특히 폐경 후 영상에 서 정상 난소를 찾는 것은 더욱 어렵다. 또한 자궁부속기 종괴가 클수록 난소를 정상 위치로부터 멀리 이동시키기 때문에 정상 난소를 확인하지 못하는 경우도 있다. 이 경우 초음파나 CT에서 자 궁각(cornual portion)에서부터 난관을 따라가며 병변의 기원을 가늠해 볼 수 있다(14). 하지만 병적으로 늘어나지 않은 정상 난관은 영상에서 확인하기 어렵고, 병변이 난관을 심하게 누르고 밀 기 때문에 대개 추적이 어렵다. 다른 유용한 방법은 CT에서 난소 정맥(ovarian vein)을 역으로 추 적하는 것이다(15). 우측 난소 정맥은 주로 동측 신정맥(renal vein)의 하단부 하대정맥(inferior vena cava)으로 연결되고 좌측은 주로 동측 신정맥으로 연결된다. 난소 정맥이 하대정맥의 우측 벽 또는 좌측 신정맥으로 연결되는 부위를 확인하고 이를 역으로 따라가면서 병변과의 연결성을 판단하거나 정상 난소를 찾을 수 있다.

\section{단순 낭종(Simple Cyst)}

난소의 단순 낭종(simple cyst)은 장액성 액체로 차 있는 낭성 질환으로 벽이 매우 얇고 내부에 
격벽(septum)과 고형 조직이 없는 경우를 일컫는다(Fig. 3). 단순 낭종은 난포형성과정의 이상으 로 발생하는 기능성 낭종(functional cyst)이 대부분이지만 양성 난소 종양일 수 있다. 수술로 제 거된 단순 난소 낭종의 병리 소견을 분석한 이전 연구에 따르면 대표적인 양성 종양인 장액낭샘종 (serous cystadenoma)은 병변이 클수록 가능성이 높고, 가임 여성보다 폐경 여성에서 호발하는 것으로 밝혀졌다(16). 따라서 여성의 연령대와 병변의 크기에 따라 단순 낭종에 대한 판단은 달라 져야 한다.

낭종의 영상 진단에 있어 낭종 내부를 채우는 액체의 성상, 격벽의 유무와 혈류 상태, 그리고 작 은 고형 조직 유무에 대한 판단은 초음파가 CT보다 유리하다(17). 따라서 CT에서 처음 발견된 난 소 병변이 단순 낭종처럼 보이더라도 다음 소견을 동반할 경우 초음파를 추가로 시행하여 단순 낭 종과 다른 질환을 감별해야 한다. 첫째, 낭종 벽이 두꺼운 경우 단순 낭종이 아닐 수 있다. 둘째, 낭 종 내부 액체의 성상이 방광 내 소변과 다를 경우, 즉 평균 CT 감쇠 계수가 $20 \mathrm{HU}$ 이상으로 높을 경우 단순 낭종이 아닐 수 있다. 셋째, 낭종 주변의 지방 조직에 반응성(reactive) 변화가 동반되어 있거나 인접한 장기와 유착이 의심되는 경우에도 단순 낭종이 아닐 가능성이 있기 때문에 초음파 검사를 권장한다. MRI는 단순 낭종과 다른 질환을 감별하는 데 있어 초음파 이상으로 정확한 검 사이지만 빈번하게 보이는 난소 낭종에 대해 일괄적으로 MRI를 시행하는 것은 비효율적이다.

\section{가임 여성의 단순 낭종}

가임 여성에서 $3 \mathrm{~cm}$ 이하의 단순 낭종은 정상 소견으로 간주하여 언급할 필요 없다. $3 \mathrm{~cm}$ 초과 $5 \mathrm{~cm}$ 이하의 경우 판독에 기술해야 하지만 여전히 추적 관찰의 대상은 아니다. $5 \mathrm{~cm}$ 초과 $7 \mathrm{~cm}$ 이 하의 경우에도 여전히 양성의 가능성이 높지만 반드시 판독에 기술하고 연 단위 초음파 추적 관찰 을 권장한다. $7 \mathrm{~cm}$ 를 초과하는 낭종은 초음파만으로 판단하기 어려운 경우가 많고 난소 종양의 가능성이 높아 CT 내지 MRI로 추가 판단해야 하며, 진단적 목적의 수술을 고려할 수도 있기 때문 에 수술 방법과 범위 결정을 위해 전이 여부도 파악하여 기술한다.

Fig. 3. Ovarian simple cyst in a 63-year-old postmenopausal woman.

A, B. Gray scale ultrasonography (A) and axial contrast-enhanced CT (B) images show a left ovarian simple cyst (arrows), measuring $4.5 \mathrm{~cm}$, without inner septum or nodule.
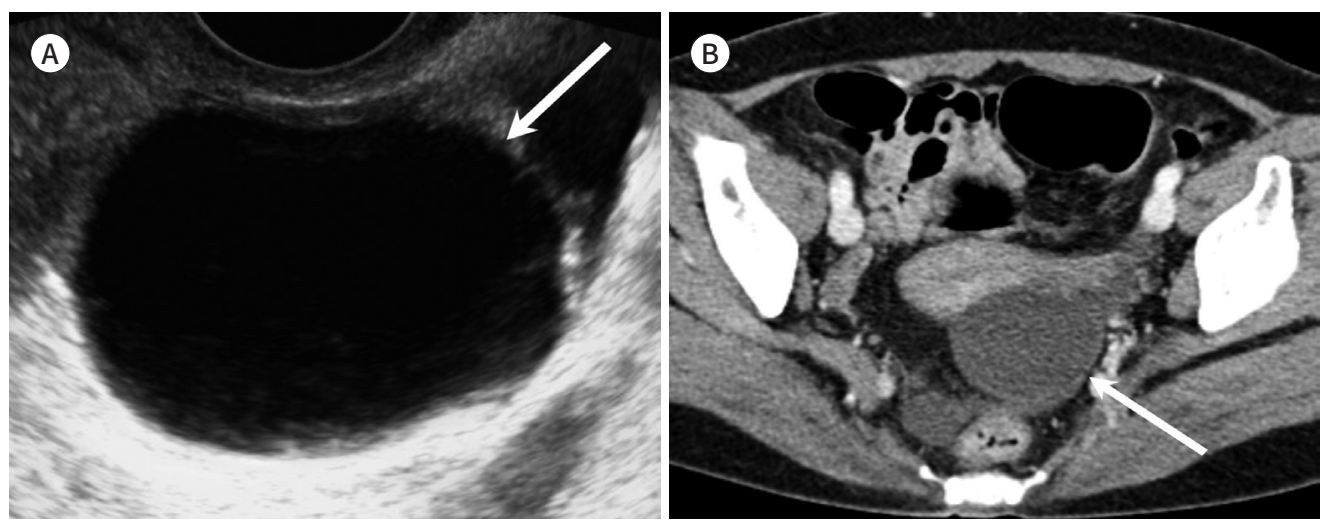


\section{폐경 여성의 단순 낭종}

한국 여성의 평균 폐경 연령은 약 49.7세이다(18). 하지만 가급적 환자 개인별 폐경 여부에 대한 정확한 정보를 파악하는 것이 중요하다. 폐경 여성에서 $1 \mathrm{~cm}$ 이하의 단순 낭종은 임상적 의미가 없는 것으로 간주하여 언급할 필요 없다. $1 \mathrm{~cm}$ 초과 $7 \mathrm{~cm}$ 이하의 경우 양성의 가능성이 높지만 반 드시 판독에 기술하고 연 단위 초음파 추적 관찰을 권장한다. $7 \mathrm{~cm}$ 를 초과하는 낭종은 가임 여성 과 마찬가지로 초음파만으로 판단하기 어려운 경우가 많고 난소 종양의 가능성이 높아 CT 내지 $\mathrm{MRI}$ 로 추가 검사하고 전이 여부도 파악하여 기술한다.

\section{여성의 정상적인 생리 주기에 따라 생성과 소멸을 반복하는 소견으로 반드시 언급할 필요는 없는 경우}

\section{황체낭(Corpus Luteum Cyst)}

황체낭은 성숙된 난포가 배란으로 인해 허탈된 후 내부에 액체가 고이면서 발생한다. 황체낭은 여성의 정상적인 생리 주기에 따라 반복적으로 나타나는 소견이므로 무증상 환자의 영상 검사에 서 우연히 발견된 경우 언급할 필요 없다. 단 황체낭 출혈에 의한 출혈성 낭종의 파열 및 혈액복강 (hemoperitoneum) 형성은 가임기 여성에서 급성 복통의 원인일 수 있다. 이 경우 낭벽의 일부에 단절이 있고 황체낭 주위를 포함한 골반강에 혈액이 차 있는 것을 확인할 수 있다.

황체낭은 초음파에서 벽이 두껍고 불규칙한 낭종으로 보이며 도플러 초음파 검사에서 낭종벽을 따라 혈류 증가 소견을 보이는 소위 'ring of fire' 징후가 특징적이다(19). CT에서도 불규칙하고 울퉁 불퉁한 낭종벽이 다소 강한 조영증강을 보인다(20). 양전자방출단층촬영(PET) 검사에서 황체낭은 강 한 섭취 증가를 보일 수 있어서 난소의 대표적인 위양성 소견이므로 판독 시 주의해야 한다(Fig. 4).

\section{판독에 기술해야 하는 양성 질환이지만 수술적 제거나 추적 관찰은 필요 없는 소견}

\section{수난관증(Hydrosalpinx)}

수난관증은 난관 원위부 폐쇄에 의한 팽대부 확장으로 발생한다. 단순 수난관증은 내부가 장액 성 액체로 차 있고 난관 내부에 뚜렷한 종괴 및 출혈이 보이지 않는 경우를 일컫는다(Fig. 5). 난소 의 병변이 아니지만 특히 초음파에서 종종 난소 낭종으로 오인된다. 단순 수난관증은 판독문에 기 술해야 할 양성 소견이지만, 수술적 제거나 추적 관찰이 반드시 필요한 소견은 아니다. 단, 불임 여 성의 원인 진단 과정에서 발견된 경우 치료 및 추적 관찰이 필요하다.

초음파 및 $\mathrm{CT}$ 에서 단순 수난관증은 내부가 장액성 액체로 채워진 관 모양의 구조물로 보이지 만, 원형 또는 타원형으로 말려있는 경우 난소 낭종으로 오인할 수 있으며, 이 경우 난관벽을 낭종 의 격벽으로 착각할 수 있다. 따라서 초음파에서 탐촉자의 방향을 바꿔보거나 CT에서 축상면 또 는 시상면으로 재구성된 영상을 활용함으로써 나누어져 보이는 낭실(cystic chamber)이 하나로 
Fig. 4. Corpus luteum cyst in a 47-year-old woman.

A. Color Doppler ultrasonography image shows an irregularly thick-walled cyst with vascular flow indicating the "ring of fire" sign (arrow).

B. Axial contrast-enhanced CT image shows a thick-walled cystic lesion with rim enhancement in the right ovary (arrow).

C. Axial PET/CT image shows strong fluorodeoxyglucose uptake in the lesion (arrow).
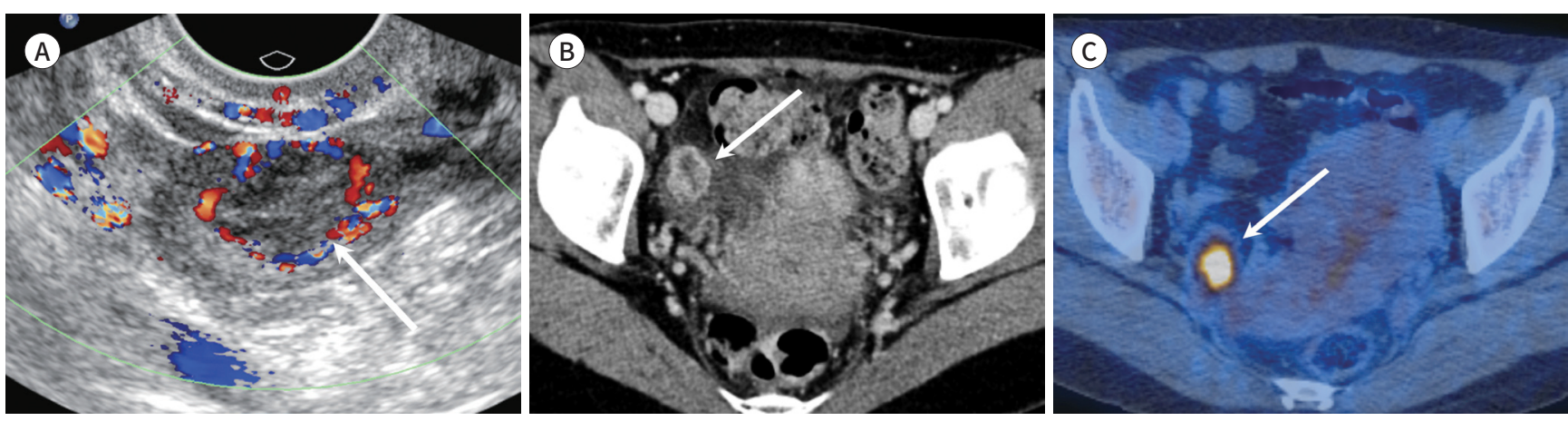

Fig. 5. Hydrosalpinx in a 50-year-old woman.

A, B. Gray scale ultrasonography (A) and axial contrast-enhanced CT image (B) show a tubular cystic structure (arrows) filled with serous fluid in the right adnexa. Each chamber of the cystic lesion is communicated, and the septum-like structures are tubal folds.
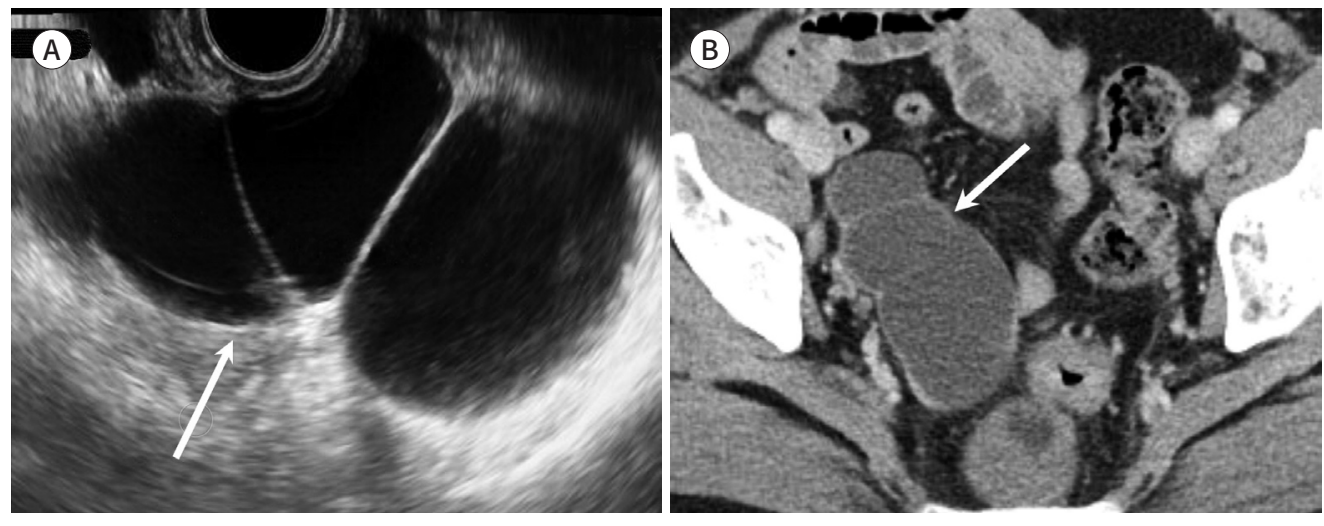

연결된 구조물이 아닌지 확인해야 한다(21). 화농난관증(pyosalpinx)은 단순 수난관증과의 감별 이 필요하다. 대개 환자는 골반통이나 발열 같은 골반감염질환(pelvic inflammatory disease)의 증상을 호소하며, 초음파에서는 늘어난 난관 내부 액체 성상이 지저분하거나 CT 상 난관벽이 두 껍고 조영증강되며 주변 지방에 반응성 변화를 확인할 수 있다(22). 난관혈종(hematosalpinx)은 자궁내막증에 흔히 동반되며 드물게 난관암과 연관된 소견일 수 있으므로 반드시 늘어난 난관 내 부에 비정상적 고형성 결절이 있는지 확인한다(23). 초음파나 CT에서 결절 여부가 모호할 경우 $\mathrm{MRI}$ 를 추가로 시행하면 진단에 도움이 될 수 있다.

\section{복막포함물낭(Peritoneal Inclusion Cyst)}

복막포함물낭은 난소에 발생하는 일차성 병변이 아니지만, 자칫 난소 병변으로 오인할 수 있는 질환이다. 골반강에 생리적으로 발생할 수 있는 체액이 복막을 통해 정상적으로 흡수되지 못할 경 우 발생한다. 골반 수술 기왕력, 자궁내막증, 골반 감염과 같이 복막 손상 및 유착을 유발할 수 있 
는 위험 인자를 확인하는 것이 진단에 유용하다. 초음파 또는 CT에서 전형적인 모습인 경우 추가 영상 검사는 필요 없고, 수술적 제거나 추적 검사가 반드시 필요하진 않다. 불필요한 추가 검사 또 는 수술을 방지하기 위해서 정확한 진단이 중요하다.

초음파 또는 CT에서 경계가 뚜렷하고 낭벽이 매우 얇은 모양의 낭성 종괴가 주변의 정상 구조 물을 감싸거나 구조물들 사이로 지나가며 눌린 양상을 보이는 것이 특징적인 소견이다(24). 주변 구조물들로 인해 쉽게 눌리기 때문에 다각형 또는 비정형 모양을 띤다. 난소에서 발생하는 병변이 아니기 때문에 복막포함물낭의 내부 또는 낭벽을 따라 정상 모양의 난소를 찾는 것이 진단에 도움 된다(Fig. 6).

\section{양성 질환이지만 수술적 제거 대상이며 제거하지 않을 경우 정기적인 추적 관찰이 필요한 소견}

\section{출혈성 낭종(Hemorrhagic Cyst)}

출혈성 낭종은 황체낭 또는 다른 기능적 낭종 내부의 생리적 출혈로 발생하는 양성 질환이다. 따라서 가임기 여성의 경우 생리 주기에 따라 얼마든지 발생할 수 있으며, 양성 출혈성 낭종은 대 개 8주 안에 자연 소실된다(25). 하지만 난소에 발생하는 종양은 내부 출혈을 동반할 수 있으며, 특 히 비상피성 종양 중 하나인 성인 과립층세포종양(adult granulosa cell tumor)은 출혈을 동반한 순수 낭종으로 보일 수 있어 간혹 양성 출혈성 낭종과의 감별이 어려울 수 있다(Fig. 7) (26). 따라 서 가임 또는 폐경기(peri-menopausal) 여성에서 발견된 $5 \mathrm{~cm}$ 초과 출혈성 낭종은 6 12주 사이 에 초음파로 추적 검사를 반드시 시행하여 병변의 변화 및 소실 여부를 확인해야 한다. $5 \mathrm{~cm}$ 이하 로 작고 초음파에서 전형적인 출혈성 낭종 소견을 보이면 추적 검사를 생략할 수도 있다. 호르몬

Fig. 6. Peritoneal inclusion cyst in a 43-year-old woman who underwent surgery for endometriosis previously.

A, B. Gray scale ultrasonography (A) and coronal T2-weighted image (B) show a large thin-walled cystic lesion (arrows) in the left adnexa. A normal ovary (arrowheads) containing small follicles is visible inside the cystic lesion.
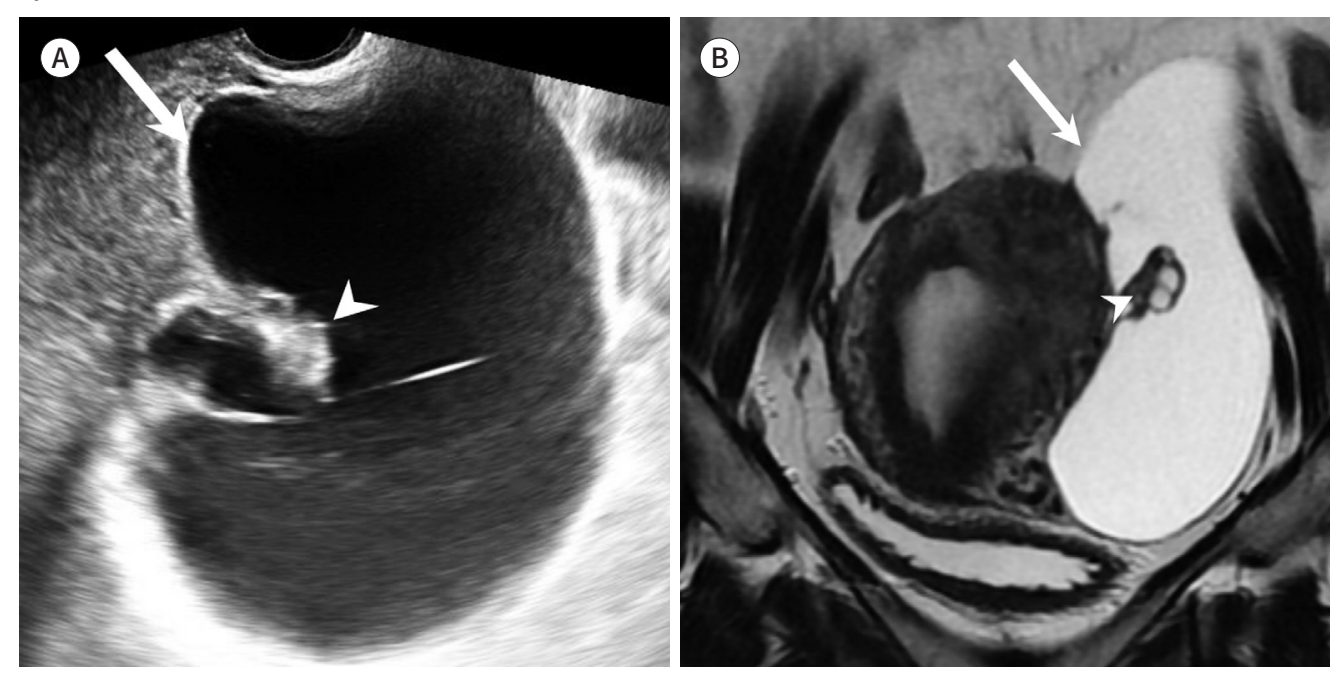
Fig. 7. Adult granulosa cell tumor mimics hemorrhagic cyst in a 44-year-old woman.

A. Initial gray scale ultrasonography shows a small lesion with interior echogenic strands (arrow) suggesting a hemorrhagic cyst inside the left ovary.

B. Follow-up color Doppler ultrasonography after 6 months shows increased size and interior blood flow of the left ovarian lesion.

C. Corresponding axial contrast-enhanced CT image shows an ill-defined low-density cystic mass (arrow) in the left ovary, which has faint hyper-dense area inside the lesion.
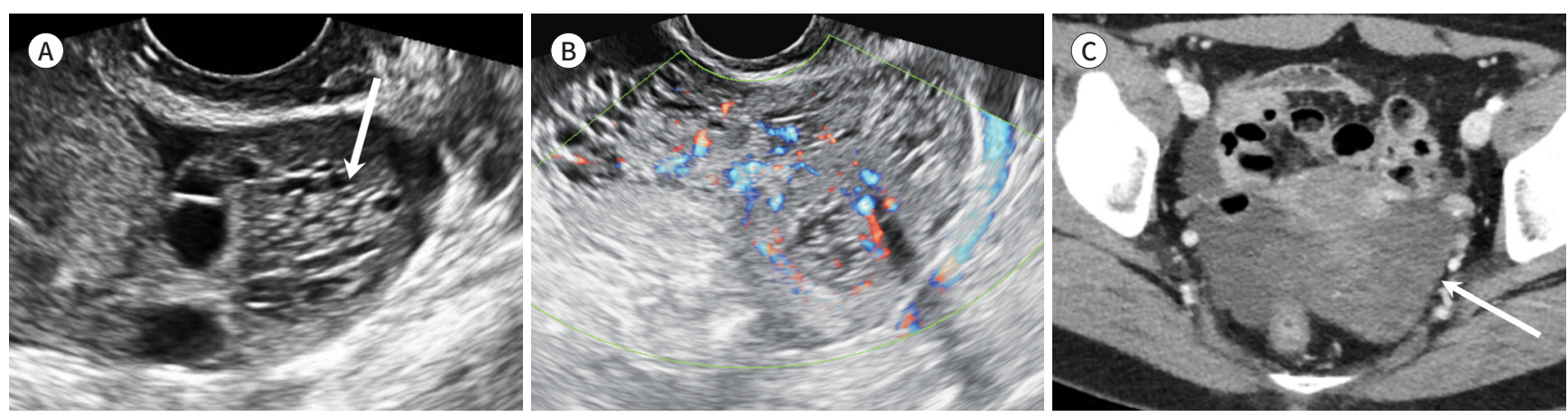

Fig. 8. Hemorrhagic cyst in a 33-year-old woman.

A. Axial contrast-enhanced CT image shows a cystic lesion (arrow) in the left ovary. The lesion shows mild wall thickening, and the mean CT attenuation value was $20 \mathrm{HU}$.

B. On color Doppler ultrasonography, fine reticular structures fill the cystic lesion (arrow), similar to cobwebs. However, the thin reticular structures do not show blood flow.
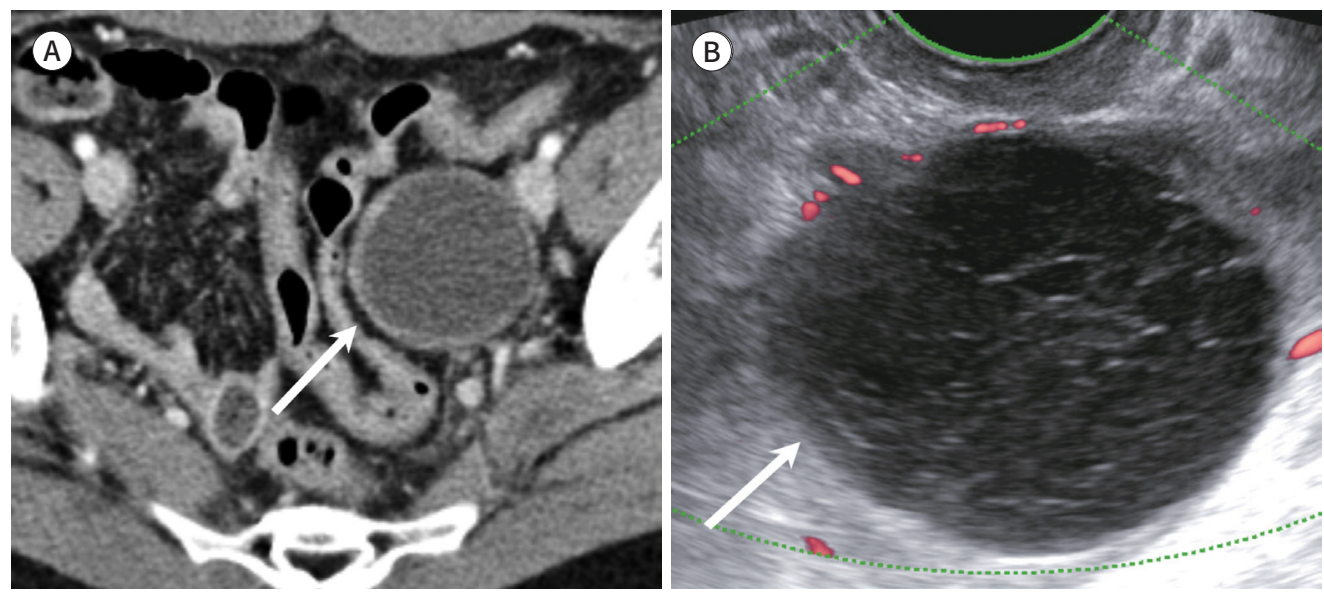

대체 치료를 받지 않는 폐경 여성의 경우 출혈성 낭종은 생리적으로 발생할 수 없기 때문에 난소 종양으로 간주한다. 즉, $\mathrm{CT}$ 또는 $\mathrm{MRI}$ 를 시행하여 병변을 추가로 평가하고 전이 여부를 언급해야 하며 대개 진단적 수술을 시행한다.

초음파에서 출혈성 낭종은 단순 낭종에 비해 낭벽의 두께는 비슷하거나 약간 두꺼울 수 있으며, 내부는 출혈 이후 시점에 따라 다양한 양상을 보인다(27). 주로 혈액이 굳고 흡수되는 과정에서 발 생하는 섬유가닥(fibrin strand)이 그물 내지 거미줄 모양으로 보여 마치 무수히 많은 격벽처럼 보 이거나 낭벽의 한쪽에 혈류는 없는 고형성 결절이 렌즈 모양으로 보이기도 한다(Fig. 8). 초음파에 서는 내부 구조가 매우 복잡하게 보여서 자칫 경계성 혹은 악성 상피 종양으로 오인될 수 있으나 격벽이나 결절처럼 보이는 부위에 혈류가 없는 것이 감별점이다. CT에서는 출혈 급성기에 낭종 내부 감쇠 계수가 매우 증가되어 있고 중력 방향에 수직으로 발생하는 소위 'fluid-fluid level' 징후 
를 보여 쉽게 진단할 수 있다. 하지만 상기 소견은 빠르게 발생하고 소실되므로, 커진 출혈성 낭종 으로 인해 환자가 급성 골반통을 호소하여 영상 검사를 시행한 경우에 발견된다. 우연히 발견된 출혈성 낭종은 CT에서 내부가 비교적 균일한 양상으로 감쇠 계수만 약간 증가한 소견을 자주 보 인다. 이 경우 CT 소견만으로 자궁내막증이나 난소농양(ovarian abscess)과 감별하기 어려운 경 우가 많으며 심지어 단순 낭종과 감별이 어려울 수도 있어서 초음파 소견이 추가로 필요하다.

\section{자궁내막증(Endometriosis)}

자궁내막증은 자궁내막 조직이 자궁 이외 부위에 비정상적으로 존재하는 질환이며, 난소에서는 낭종 형태로 나타난다. 자궁내막증은 수술적 제거가 필요하며 그 이유는 다음과 같다(28). 첫째, 반 복적인 골반통을 일으킬 수 있고 가임기 여성에서 불임의 가장 흔한 원인이다. 둘째, 염전이나 파 열의 가능성이 있다. 셋째, 내부에 악성 종양이 병발할 수 있는데 조직학적으로 가장 흔한 것은 자 궁내막모양샘암(endometrioid adenocarcinoma)이며 그 다음은 투명세포암(clear cell carcino$\mathrm{ma}$ ) 이다(29). 만약 수술로 제거하지 않는 경우, 추적 검사 주기에 관한 명확한 가이드라인은 없지 만 최소 연 1 회 이상의 초음파 검사를 통해 병변의 크기 변화와 합병증 발생 유무를 판단해야 한다.

초음파는 자궁내막증을 진단하는 매우 유용한 일차 검사이다(30). 초음파에서 낭종 내부는 균일 한 저에코로 보이고 낭종벽을 따라 혈류가 없는 작은 고에코 부위가 보일 수 있다(31). 앞서 언급 한 대로 CT에서 처음 발견된 병변에서는 출혈성 낭종, 자궁내막증, 난소농양을 배제하기 어려운 경우가 많아 필요시 초음파를 추가로 시행하여 진단한다(Fig. 9). 병변의 위치나 크기로 인해 초음 파만으로 평가하기 어려운 경우 또는 도플러 검사에서 내부 혈류를 동반한 고형성 결절이 의심되 는 경우 MRI를 추가로 시행하여 평가한다(32). 암이 발생하는 경우 대개 자궁내막증의 크기가 $9 \mathrm{~cm}$ 이상으로 크며, 조영증강을 동반한 결절이 흔히 동반된다(Fig. 10) (33).

Fig. 9. Endometriosis in a 42-year-old woman.

A. Axial contrast-enhanced CT image shows cystic lesion (arrow) in the left ovary. The lesion shows mild wall thickening, and the mean CT attenuation value is $26 \mathrm{HU}$. The imaging feature is similar to a hemorrhagic cyst. B. Unlike hemorrhagic cysts, the interior texture of the ovarian cyst (arrow) is predominantly homogeneous on color Doppler ultrasonography without blood flow.
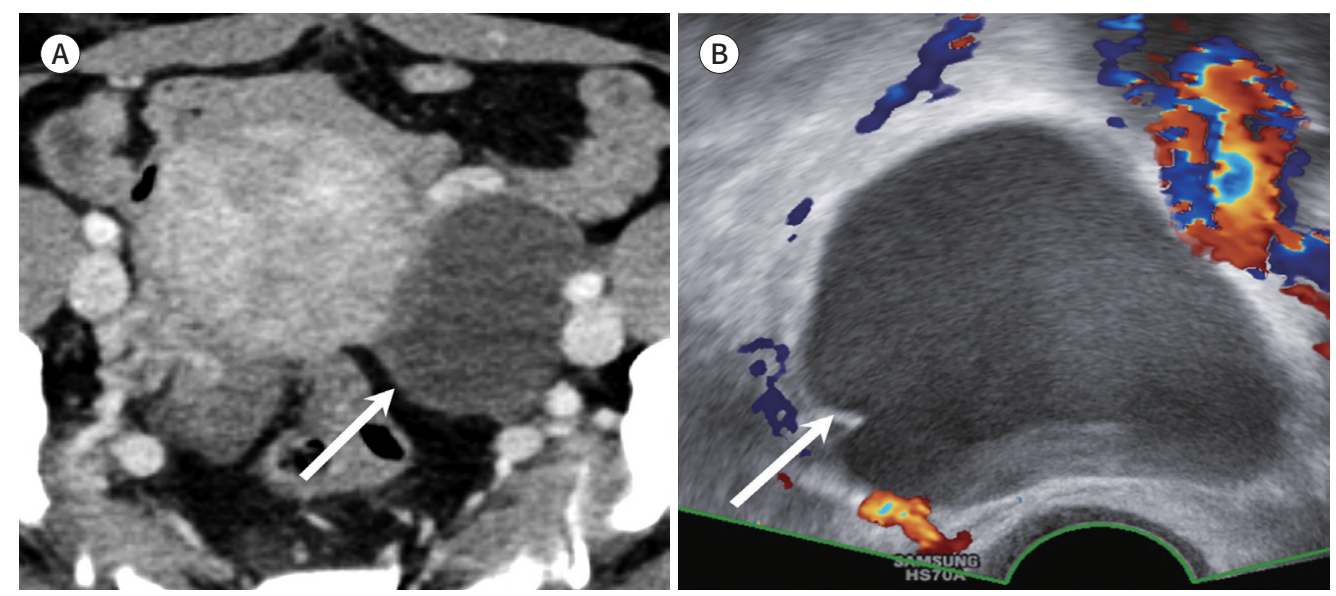


\section{성숙기형종(Mature Teratoma)}

성숙기형종은 난소에 발생하는 생식세포 종양 중 가장 흔하며, 45세 이하 여성에서 가장 흔한 양성 난소 종양이다(34). 성숙기형종은 양성 질환이지만 다음과 같은 합병증을 동반할 수 있어 수 술로 제거하는 것이 원칙이다. 첫째, 가장 흔한 합병증으로 난소 염전을 일으킬 수 있다. 둘째, 드 물지만 파열의 가능성이 있다. 셋째, 보고된 발생 빈도가 0.17 2\%로 매우 드물지만 악성전환(malignant transformation) 할 수 있으며, 조직학적으로 대부분 편평상피세포암(squamous cell carcinoma)이 발생한다 $(35,36)$. 악성전환은 특히 50 세 이후 폐경기 여성에서 상대적으로 흔하다. CT에서 강한 조영증강을 동반한 연부 조직이 주변으로 침습하는 양상을 띤다면 악성전환의 가능 성을 언급해야 한다(37). 수술로 제거하지 않은 성숙기형종은 나이와 상관없이 진단 후 첫 6개월, 이후 연 단위로 초음파 내지 CT를 통해 병변 크기와 내부 성상의 변화를 평가해야 한다.

성숙기형종은 $90 \%$ 이상에서 지방성분을, $50 \%$ 에서 석회화를 동반하고 있으므로 이러한 특징적 인 소견을 초음파 또는 CT에서 확인해야 한다 $(38,39)$. 초음파에서는 공기를 포함한 주변의 장, 출혈 성 낭종, 그리고 기타 낭성 난소 종양과 감별이 어려울 수 있으며, 이 경우 CT를 시행하여 내부 지방 성분을 확인하면 진단이 쉽다(Fig. 11). 대개 CT에서 진단 가능하며 MRI 추가 검사는 필요 없다.

\section{섬유종(Fibroma)}

섬유종(fibroma) 또는 섬유난포막종(fibrothecoma)은 난소에 발생하는 가장 흔한 양성 성끈 기질종양(sex-cord stromal tumor)이며, 폐경 여부와 상관 없이 전 연령대에서 발생할 수 있다. 양성 질환이기 때문에 정기적인 초음파 검사를 시행하여 병변의 크기 및 내부 성상 변화를 평가하 는 것으로 충분하지만, 클수록 난소 염전의 원인이 될 수 있기 때문에 수술로 제거하기도 한다. 이 질환은 초음파에서 경계가 좋고 균일한 저에코 병변으로 보이며 내부 성상은 자궁 근종과 유사한

Fig. 10. Clear cell carcinoma arising from endometriosis in a 39-year-old woman.

A. Color Doppler ultrasonography image shows a large cystic ovarian mass, which is filled with homogeneous and diffuse hypoechoic material suggesting underlying endometriosis. Inner hyperechoic mass (asterisk) shows blood flow.

B. Coronal contrast-enhanced CT image shows a large cystic mass (arrow) containing an inner solid component (asterisk) with enhancement.
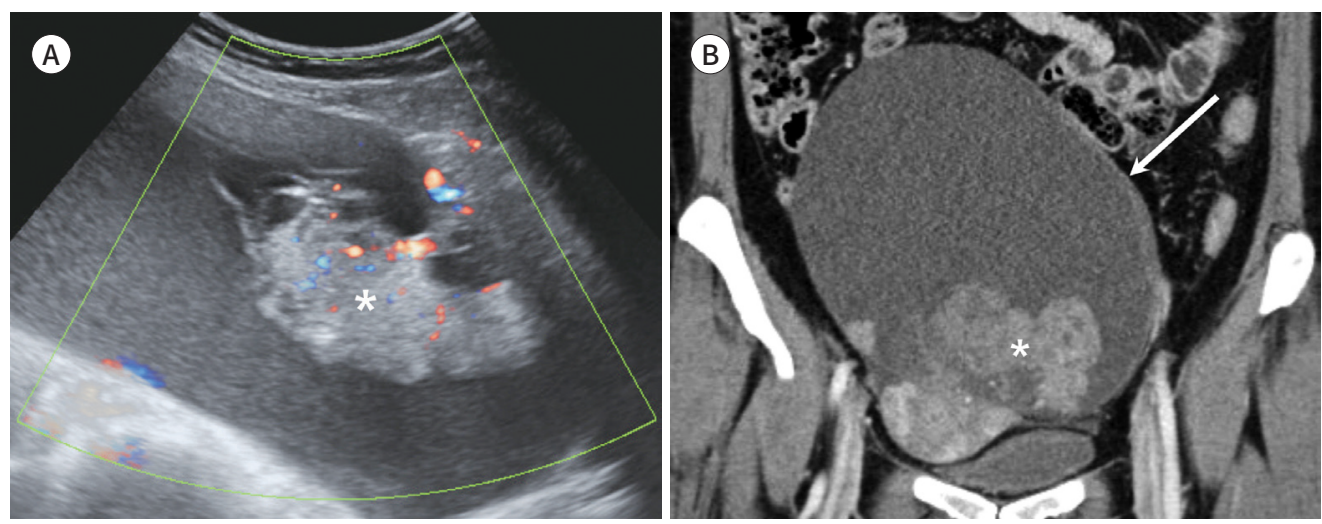
양상이다. 하지만 내부 변성 정도에 따라 다양한 초음파 양상을 보일 수 있다. 마찬가지로 CT에서 도 비교적 균일한 양상을 보이며 지연기 조영증강을 동반한다. 하지만 지연기 영상이 없는 경우 내부 조영증강 여부를 판단할 수 없어서 낭종과의 감별이 어려울 수 있다. 이 경우 MRI의 T2 강조 영상에서 특징적으로 낮은 신호 강도를 확인하면 진단할 수 있다(Fig 12) (40).

\section{경계성 또는 악성 종양의 가능성이 있어서 추가 검사 내지 진단적 수술이 필요한 경우}

초음파에서 다음 소견을 보이는 경우 난소 종양의 가능성을 배제할 수 없거나 난소 종양을 시사 하는 소견이기 때문에 추가 검사를 시행하거나 수술로 제거해야 한다.

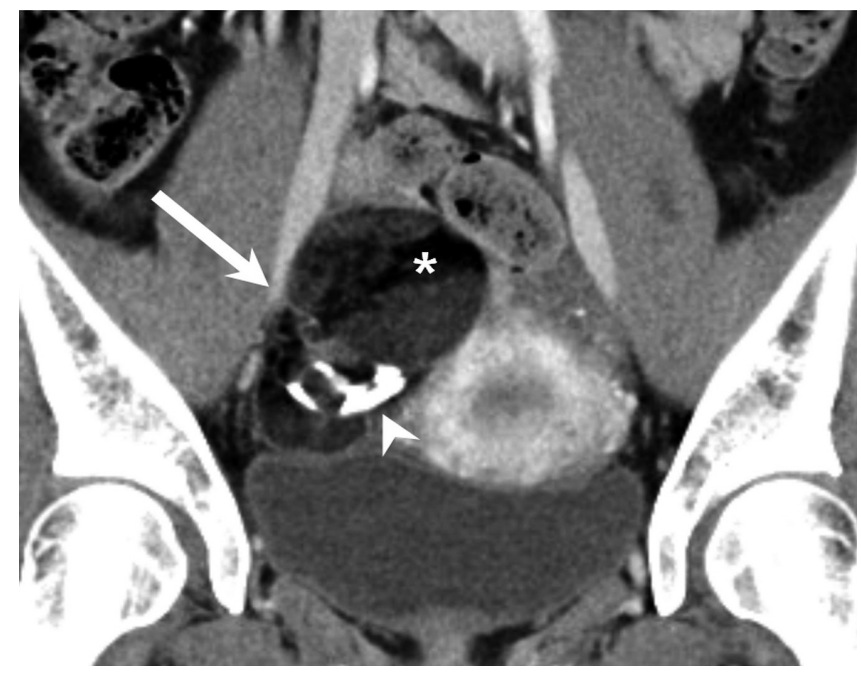

Fig. 12. Fibroma in a 61-year-old woman.

A. Axial contrast-enhanced CT image at the portal phase shows a well-defined homogeneous mass in the right ovary (arrow). The mean CT attenuation value is $40 \mathrm{HU}$, which is not significantly different from $32 \mathrm{HU}$ on the pre-contrast image.

B. On the axial T2-weighted image, the lesion (arrow) shows diffuse low signal intensity, suggesting a fibrotic component.
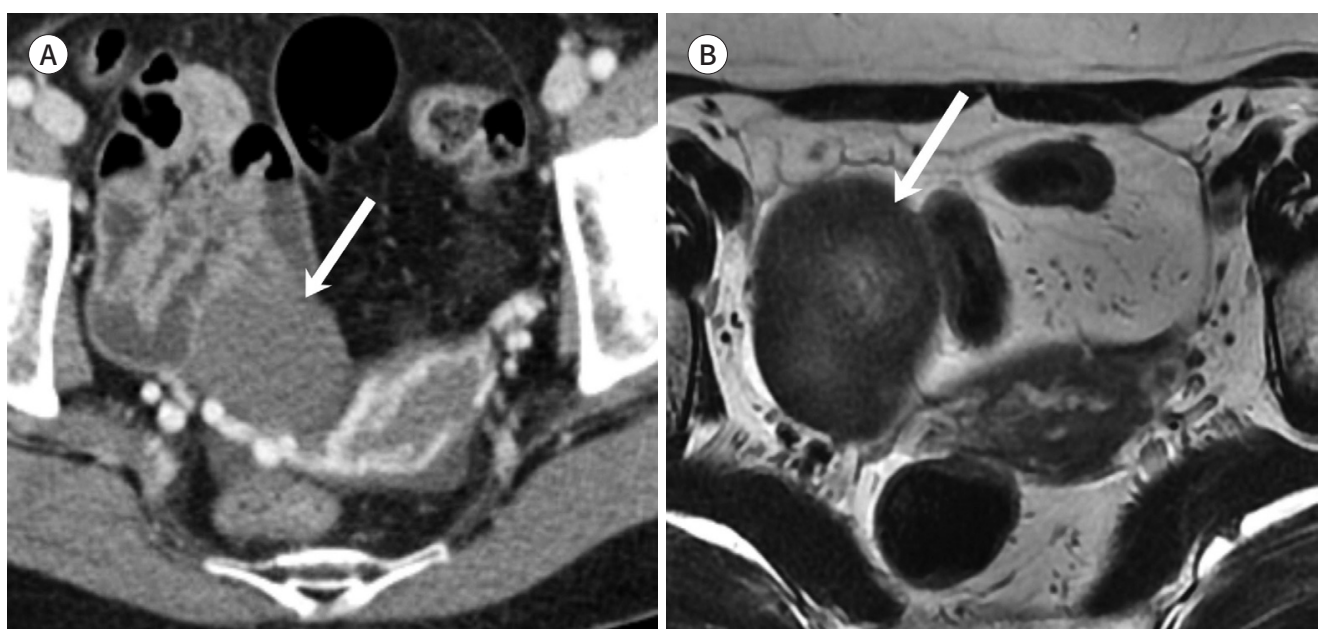
첫째, 초음파에서 출혈성 낭종, 자궁내막증, 또는 성숙기형종 등의 질환이 의심되지만 확실하지 않은 경우이다. 폐경 전 여성의 경우 상기 질환의 감별이 어렵다면 출혈성 낭종의 가능성을 고려 하여 6 12주 사이 초음파로 추적하여 크기 감소나 소실을 기대해 본다. 만약 변화가 없거나 커진 경우 MRI를 시행할 것을 권고하며, MRI에서도 상기 질환 중 어느 하나로 명확히 진단할 수 없다 면 수술을 고려해야 한다. 폐경 여성의 경우는 바로 진단적 수술을 고려한다.

둘째, 초음파에서 병변 내부에 얇은 격벽이나 고형성 결절이 보이지만 도플러 검사에서 내부 혈 류는 보이지 않는 경우이다. 단 두께 $3 \mathrm{~mm}$ 미만의 단일 격벽만 보이거나 매우 작은 낭벽 석회화 가 동반된 경우는 단순 낭종에 준하여 판단한다. 두께 $3 \mathrm{~mm}$ 미만의 얇은 격벽이 여러 개 보이거 나 혈류는 없는 결절이 보인다면 장액낭샘종이나 낭샘섬유종(cystadenofibroma) 같은 양성 종양 일 가능성이 높으며 수술로 제거해야 한다. 만약 도플러 검사에서 혈류 평가가 모호한 경우 수술 방법과 범위를 결정함에 있어 악성 종양의 가능성을 배제하기 위해 MRI를 시행하여 격벽이나 결 절의 조영증강 여부를 추가로 평가할 수 있다(41).

셋째, 격벽이 $3 \mathrm{~mm}$ 이상으로 두껍고 불규칙하거나 내부 혈류를 동반한 고형성 결절이 보이는 경우 경계성 내지 악성 종양의 가능성이 있으므로 나이와 상관없이 수술로 제거해야 한다(2).

$\mathrm{CT}$ 는 앞서 언급한 대로 초음파에 비해 낭종 내부의 얇은 격벽이나 작은 결절 평가에 있어 민감 도가 떨어진다. 게다가 단순 낭종, 출혈성 낭종, 그리고 자궁내막증의 감별이 어려운 경우도 있다. 하지만 CT에서 처음 발견한 난소 낭종에 뚜렷한 격벽 또는 고형성 결절이 보인다면 해당 병변은 난소 종양의 가능성이 매우 높고 수술로 제거해야 한다. 더구나 상기 구조물에 뚜렷한 조영증강이 보이면 경계성 내지 악성 종양의 가능성도 있다. 이 경우 CT는 종양의 복막 파종(peritoneal seeding)이나 전이 여부를 판단하여 수술의 방법과 범위를 결정하는 데 매우 유용하다(42). 만약 CT에 서 격벽 또는 고형성 결절이 보이지만 조영증강이 불분명한 경우 수술 여부를 결정하기 전 $\mathrm{MRI}$ 를 이용한 해당 부위의 추가적인 평가가 도움이 될 수 있다.

\section{결론}

난소에서 우연히 접하는 병변 중 특히 낭종은 추가 검사나 치료가 필요하지 않은 생리적 소견 내 지 양성 질환으로부터 반드시 치료가 필요한 악성 종양까지 매우 넓은 범위의 질환들을 포함한다. 우연히 발견된 난소 병변을 진단하고 추적 관찰함에 있어 가장 기본적이고 유용한 검사는 초음파 이다. CT에서 처음 발견된 경우 오히려 초음파 검사를 시행하여 병변을 진단하고 추후 조치를 결정 할 필요가 있다. MRI는 낭종 내부의 격벽이나 고형성 결절에 대한 판단이 초음파나 CT로 제한적인 경우 고려한다. 난소의 단순 낭종은 여성의 가임 연령대와 병변의 크기에 따라 판단이 달라져야 한 다. 그 외 다른 질환에 대해서도 비단 진단을 위한 영상 소견의 이해와 적용뿐 아니라, 추가 또는 추 적 검사의 필요성에 대한 영상의학과 의사의 판단 역시 난소 병변을 평가함에 있어 필수적이다.

\section{Author Contributions}

Conceptualization, all authors; data curation, K.S., P.J.J.; formal analysis, all authors; funding acquisition, P.J.J.; investigation, K.S., P.J.J.; methodology, P.J.J., P.S.Y.; project administration, P.J.J.; resourc- 
es, all authors; software, K.S.; supervision, P.J.J., P.S.Y.; validation, P.J.J., P.S.Y.; visualization, all authors; writing-original draft, K.S., P.J.J.; and writing-review \& editing, P.J.J., P.S.Y.

\section{Conflicts of Interest}

The authors have no potential conflicts of interest to disclose.

\section{REFERENCES}

1. Liu J, Xu Y, Wang J. Ultrasonography, computed tomography and magnetic resonance imaging for diagnosis of ovarian carcinoma. Eur J Radiol 2007;62:328-334

2. Brown DL, Doubilet PM, Miller FH, Frates MC, Laing FC, DiSalvo DN, et al. Benign and malignant ovarian masses: selection of the most discriminating gray-scale and Doppler sonographic features. Radiology 1998;208:103-110

3. Granberg S, Wikland M, Jansson I. Macroscopic characterization of ovarian tumors and the relation to the histological diagnosis: criteria to be used for ultrasound evaluation. Gynecol Oncol 1989;35:139-144

4. Fader AN, Rose PG. Role of surgery in ovarian carcinoma. J Clin Oncol 2007;25:2873-2883

5. Timmerman D, Testa AC, Bourne T, Ameye L, Jurkovic D, Van Holsbeke C, et al. Simple ultrasound-based rules for the diagnosis of ovarian cancer. Ultrasound Obstet Gynecol 2008;31:681-690

6. Barney SP, Muller CY, Bradshaw KD. Pelvic masses. Med Clin North Am 2008;92:1143-1161, xi

7. Levine D, Brown DL, Andreotti RF, Benacerraf B, Benson CB, Brewster WR, et al. Management of asymptomatic ovarian and other adnexal cysts imaged at US: Society of Radiologists in Ultrasound Consensus Conference Statement. Radiology 2010;256:943-954

8. Cohen HL, Tice HM, Mandel FS. Ovarian volumes measured by US: bigger than we think. Radiology 1990; 177:189-192

9. Bakos O, Lundkvist O, Wide L, Bergh T. Ultrasonographical and hormonal description of the normal ovulatory menstrual cycle. Acta Obstet Gynecol Scand 1994;73:790-796

10. Ritchie WG. Sonographic evaluation of normal and induced ovulation. Radiology 1986;161:1-10

11. Baerwald AR, Adams GP, Pierson RA. Form and function of the corpus luteum during the human menstrual cycle. Ultrasound Obstet Gynecol 2005;25:498-507

12. Sokalska A, Valentin L. Changes in ultrasound morphology of the uterus and ovaries during the menopausal transition and early postmenopause: a 4-year longitudinal study. Ultrasound Obstet Gynecol 2008;31:210217

13. Healy DL, Bell R, Robertson DM, Jobling T, Oehler MK, Edwards A, et al. Ovarian status in healthy postmenopausal women. Menopause 2008;15:1109-1114

14. Foshager MC, Walsh JW. CT anatomy of the female pelvis: a second look. Radiographics 1994;14:51-64; discussion 64-66

15. Lee JH, Jeong YK, Park JK, Hwang JC. "Ovarian vascular pedicle" sign revealing organ of origin of a pelvic mass lesion on helical CT. AJR Am J Roentgenol 2003;181:131-137

16. Castillo G, Alcázar JL, Jurado M. Natural history of sonographically detected simple unilocular adnexal cysts in asymptomatic postmenopausal women. Gynecol Oncol 2004;92:965-969

17. Kurtz AB, Tsimikas JV, Tempany CM, Hamper UM, Arger PH, Bree RL, et al. Diagnosis and staging of ovarian cancer: comparative values of Doppler and conventional US, CT, and MR imaging correlated with surgery and histopathologic analysis--report of the Radiology Diagnostic Oncology Group. Radiology 1999;212:19-27

18. Kim IK, Choi HM, Kim MH. Menopausal knowledge and management in peri-menopausal women. J Korean Soc Menopause 2012;18:124-131

19. Bonde AA, Korngold EK, Foster BR, Fung AW, Sohaey R, Pettersson DR, et al. Radiological appearances of corpus luteum cysts and their imaging mimics. Abdom Radiol (NY) 2016;41:2270-2282

20. Borders RJ, Breiman RS, Yeh BM, Qayyum A, Coakley FV. Computed tomography of corpus luteal cysts. J ComputAssist Tomogr 2004;28:340-342

21. Patel MD, Acord DL, Young SW. Likelihood ratio of sonographic findings in discriminating hydrosalpinx from other adnexal masses. AJRAm J Roentgenol 2006;186:1033-1038

22. Birnbaum BA, Jeffrey RB Jr. CT and sonographic evaluation of acute right lower quadrant abdominal pain. AJR Am J Roentgenol 1998;170:361-371 
23. Ko ML, Jeng CJ, Chen SC, Tzeng CR. Sonographic appearance of fallopian tube carcinoma. J Clin Ultrasound 2005;33:372-374

24. Guerriero S, Ajossa S, Mais V, Angiolucci M, Paoletti AM, Melis GB. Role of transvaginal sonography in the diagnosis of peritoneal inclusion cysts. J Ultrasound Med 2004;23:1193-1200

25. Okai T, Kobayashi K, Ryo E, Kagawa H, Kozuma S, Taketani Y. Transvaginal sonographic appearance of hemorrhagic functional ovarian cysts and their spontaneous regression. Int J Gynaecol Obstet 1994;44:47-52

26. Ko SF, Wan YL, Ng SH, Lee TY, Lin JW, Chen WJ, et al. Adult ovarian granulosa cell tumors: spectrum of sonographic and CT findings with pathologic correlation. AJRAm J Roentgenol 1999;172:1227-1233

27. Jain KA. Sonographic spectrum of hemorrhagic ovarian cysts. J Ultrasound Med 2002;21:879-886

28. Vercellini P, Viganò P, Somigliana E, Fedele L. Endometriosis: pathogenesis and treatment. Nat Rev Endocrinol 2014;10:261-275

29. Kawaguchi R, Tsuji Y, Haruta S, Kanayama S, Sakata M, Yamada Y, et al. Clinicopathologic features of ovarian cancer in patients with ovarian endometrioma. J Obstet Gynaecol Res 2008;34:872-877

30. Brosens I, Puttemans P, Campo R, Gordts S, Brosens J. Non-invasive methods of diagnosis of endometriosis. Curr Opin Obstet Gynecol 2003;15:519-522

31. Patel MD, Feldstein VA, Chen DC, Lipson SD, Filly RA. Endometriomas: diagnostic performance of US. Radiology 1999;210:739-745

32. Siegelman ES, Oliver ER. MR imaging of endometriosis: ten imaging pearls. Radiographics 2012;32:16751691

33. Kobayashi H, Sumimoto K, Kitanaka T, Yamada Y, Sado T, Sakata M, et al. Ovarian endometrioma--risks factors of ovarian cancer development. Eur J Obstet Gynecol Reprod Biol 2008;138:187-193

34. Caspi B, Appelman Z, Rabinerson D, Elchalal U, Zalel Y, Katz Z. Pathognomonic echo patterns of benign cystic teratomas of the ovary: classification, incidence and accuracy rate of sonographic diagnosis. Ultrasound Obstet Gynecol 1996; 7:275-279

35. Hackethal A, Brueggmann D, Bohlmann MK, Franke FE, Tinneberg HR, Münstedt K. Squamous-cell carcinoma in mature cystic teratoma of the ovary: systematic review and analysis of published data. Lancet Oncol 2008;9:1173-1180

36. Rim SY, Kim SM, Choi HS. Malignant transformation of ovarian mature cystic teratoma. Int J Gynecol Cancer 2006;16:140-144

37. Park SB, Cho KS, Kim JK. CT findings of mature cystic teratoma with malignant transformation: comparison with mature cystic teratoma. Clin Imaging 2011;35:294-300

38. Mais V, Guerriero S, Ajossa S, Angiolucci M, Paoletti AM, Melis GB. Transvaginal ultrasonography in the diagnosis of cystic teratoma. Obstet Gynecol 1995;85:48-52

39. Patel MD, Feldstein VA, Lipson SD, Chen DC, Filly RA. Cystic teratomas of the ovary: diagnostic value of sonography. AJR Am J Roentgenol 1998;171:1061-1065

40. Troiano RN, Lazzarini KM, Scoutt LM, Lange RC, Flynn SD, McCarthy S. Fibroma and fibrothecoma of the ovary: MR imaging findings. Radiology 1997;204:795-798

41. Iyer VR, Lee SI. MRI, CT, and PET/CT for ovarian cancer detection and adnexal lesion characterization. AJR Am J Roentgenol 2010;194:311-321

42. Forstner R. Radiological staging of ovarian cancer: imaging findings and contribution of CT and MRI. Eur Radiol 2007;17:3223-3235 


\section{우연히 접하는 난소 병변}

강성수 ${ }^{*} \cdot$ 박정재 $^{1,2 *} \cdot$ 박성윤 $^{3}$

우연히 접하는 난소 병변은 정상 소견부터 악성 종양까지 매우 넓은 범위의 질환을 포함하기 때문에 진단이 어렵다. 일부 난소 병변은 추적 검사나 치료가 불필요하다. 어떤 영상 소견은 양성 난소 질환을 시사하는 반면 악성 가능성을 시사하는 중요한 영상 소견들도 있다. 따라 서 영상의학과 의사의 정확한 영상 판독과 임상 의사를 위한 적절한 권고는 우연히 접하는 난소 병변에 대한 불필요한 검사나 침습적인 치료를 방지하고 올바르게 대응하기 위해 필수 적이다. 본 종설의 목적은 흔하게 접하는 난소 병변의 초음파 및 $\mathrm{CT}$ 소견을 기술하고 난소 병 변의 악성 가능성에 따른 대응 방안을 설명하고자 한다.

1충남대학교병원 영상의학과, ${ }^{2}$ 충남대학교 의과대학 영상의학과, 3성균관대학교 의과대학 삼성서울병원 영상의학과 